\title{
Waqf for Higher Education in Malaysia: Overview on Challenges
}

\author{
Professor Dr. Wan Kamal Mujani \\ Dean, Faculty of Islamic Studies, National University of Malaysia, Bangi, Selangor Darul Ihsan, Malaysia. \\ Professor Dato Dr. Noor Inayah Yaakub \\ Dean, Faculty of Business \& Accountancy, University of Selangor (UNISEL), Malaysia.
}

\begin{abstract}
In Malaysian higher learning institutions of public or private universities, the generation of income through endowments are recently highly recommended for financial or self-sustainability. Public universities especially, as a non-profit organisation strong endowments reflect the capacity to obtain revenues through grants or otherwise in response to a demand, in order to sustain productive processes projects at a steady or growing rate which eventually produce results and thus accomplish the mission, goals, or objectives and to obtain a surplus. However, the implementation of waqf in universities in Malaysia is not easy. Unlike endowments or other forms of income generation tools for universities, waqf is very unique and subject not only to legal restrictions but also religious principles that must be fulfilled. The paper finds that universities in Malaysia need to bear in mind the challenges of to avoid difficulties in implementing waqf.
\end{abstract}

Keywords: Waqf for Higher Education in Malaysia: Overview on Challenges

\section{Introduction}

Another instrument recognised as the most flexible instrument for financing universities is waqf (Kartini et al. 2015; M. K. Izwan et al. 2014). However, waqf itself is not an easy concept since it is religious in nature and therefore, its principles must be clearly understood. In addition, the legal framework and its strict rules under Islamic law make it more complex for universities in Malaysia to implement. State Islamic Religious Council for example is the main authority who has an exclusive power on matters concerning waqf (M. K. Izwan et al. 2016). It is the main aim of this paper to explore prospects and challenges on waqf for higher learning institutions in Malaysia.

The paper relates few concepts of waqf with the implementation in the university. Few main concepts of waqf should be adhered to for instance, A Giver (al-Wakif) is a party that willingly gives movable or immovable, lawfully-owned assets (alMawquf) for an intended purpose (Niyyah) to benefit others (beneficiaries). Waqf allows a Giver the opportunity to demonstrate his/her submission to Allah through good deeds. In addition, waqf provides an avenue for the public to perform perpetual deeds with confidence. Secondly, in Malaysian context, a MAIN (State Islamic Religious Council) is the sole trustee (Mutawalli) of waqf in its respective state. Therefore, public universities must acquire the permission from MAIN to be a waqf administrator (Nazir), so university's administrator must settle this hurdle first in order to implement waqf in the university (Nor Suziana \& Noor Inayah 2017a; Nor Suziana \& Noor Inayah 2017b).

As a waqf administrator, public universities are empowered by MAIN to establish a sustainable infrastructure which will allow them to collect, raise, use, manage, invest, and develop waqf funds, as well as distribute waqf proceeds as agreed in the MoA between the public university and the respective MAIN. Universities must use all of their expertise, tools, strategies to ensure the growth of waqf and that the waqf is Syariah compliance (Mohd Syakir et al. 2017). This can only be achieved by having a proper waqf office and governance structure at the university. Waqf administrators can adopt 
various strategies to monetise waqf assets. Finally, the proceeds from waqf investment may be distributed to Muslims or non-Muslims. The benefits to the beneficiaries can be in various forms, including: scholarships and other academic financial support, grants for research, academic or professorial chairs, traveling allowances for conferences as well as sponsorships for academic and research programme (Mohd Syakir et al. 2016).

\section{Pillars of Waqf}

The Department of Awqaf, Zakat, and Hajj, Malaysia (JAWHAR) epitomizes waqf as any form of asset belong to individual which has been endowed as waqf and it is restricted for any form of dealing such as sale, inheritance, gift and inheritance. However, its physical source remains intact and unchanged. Three pillars of waqf are as follows:

\section{Irrevocability}

Most important feature of waqf as there is consensus among Muslim jurists that a waqf is irrevocable once a founder declares his property as waqf, and his heirs cannot change its status. This will ensure that the waqf will continue to benefit the society and at the same time the founder/giver will continue to get rewards from Allah.

\section{Perpetuity}

The majority of Muslim jurists agreed that the waqf must be perpetual once it is created. This will ensure that no confiscation of waqf property will take place either by government or individuals, and will ensure continual support from this waqf towards financing charitable causes. Only in the Maliki School of Law is it permissible to allow the creation of a waqf for a limited time.

\section{Inalienability}

This feature originates from the concept that the property of waqf is transferred to Allah, although the usufruct derived from it can benefit mankind. All Muslim jurists agreed that no one can ever become the owner to alienate it and that waqf property is thus in nature, like a 'frozen asset'. It cannot be subject to any sale, disposal, mortgage, gift, inheritance or any alienation. Waqf is inalienable except when there is an exchange of property of equal value (Wan Kamal 2014).

\section{Tenets of Waqf}

The tenets of waqf are:

i. The Giver (al-Wakif) is an individual or an organization who surrender an asset as waqf and designate its beneficiary.

ii. The Clear Statement (al-Sighah) made by the Giver when surrendering his assets for purpose of waqf.

iii.The Designated Asset (al-Mawkuf) surrendered must be in compliance with the Sharia and rightfully owned by the Giver. iv. The Beneficiary (al-Mawkuf 'Alaihi) can be an individual(s) or an institution(s) which is awarded the income generated from investing the waqf (Wan Kamal et al. 2012).

\section{Examples on Waqf by selected Universities in Malaysia}

1. Technology University of Malaysia (UTM)

UTM is one of the public research universities which have coherent set of university funds including waqf. Below is the example of the varieties of funds of UTM. 


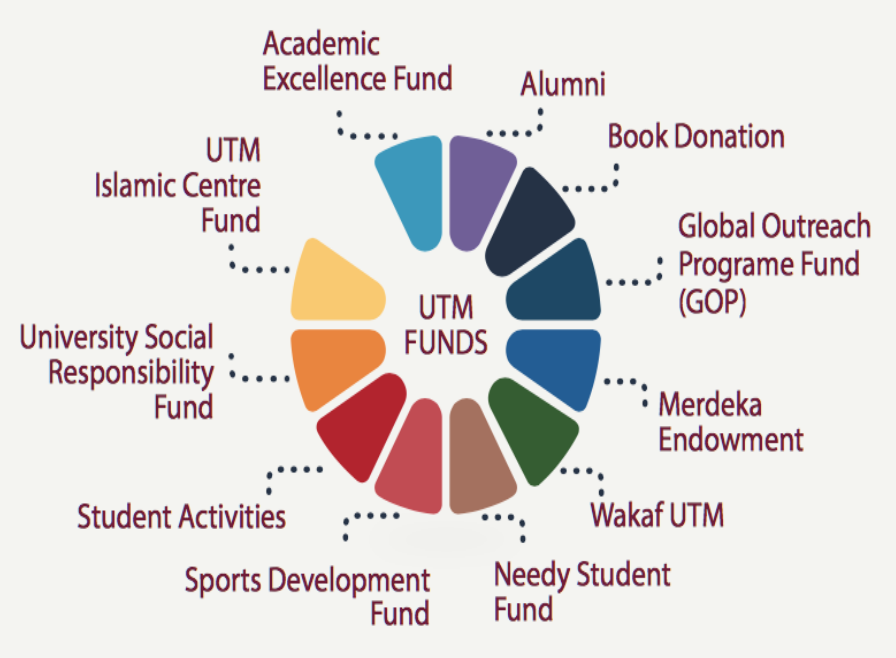

UTM has also made it clear the difference between endowment and waqf.

2. Islamic University of Malaysia (UIM)

Historically, Islamic University of Malaysia (UIM) was established on 24 February 1955 and formerly known as Kolej Islam Malaya (Muslim College Malaya/KIM). It is the first university that was established with the consent of the Conference of Malay Rulers. UIM is currently operating in Cyberjaya with the blessings and approval of the Ministry of Higher Education. The history of UIM development is based on the waqf concept which began with the waqf by Sultan of Selangor who donated Istana Jameah (Jameah Palace) in Kampung Jawa in 1955 to be a KIM campus which symbolized educational progress in Malaya. In line with its establishment, UIM is obliged to inspire any form of waqf contribution in furthering the mission of IUM establishment until it becomes a university that continues to grow on Islamic endowments without solely depending on government contributions and that also has freedom in knowledge and intellectual development (Wan Kamal et al. 2016a; Wan Kamal et al. 2014).

All waqf matters of UIM will be monitored and advised by a panel known as the 'Shariah Panel' consisting of experts who are authoritative in Shariah law (http://www.uim.edu.my/v2/index.php/faw). UIM has received waqf income and contributions from numerous resources such as from leasing of waqf lands and waqf premises belonging to UIM, waqf donations from individual and corporate bodies including the alumni of Islamic College (ALKIS) and also contributions from State Islamic Religious Councils (SIRC) (as certified by the Conference of Rulers) and from Federal Government of Malaysia (Federal Constitution; Malaysia Companies Act 1965). UIM has received financial supports around 5.18 million MYR from several donors. Among of them are Permodalan Berhad (PNB) 5 million MYR, Shahpadu Corp. Sdn. Bhd., Datuk Dr. Haron Din as a former student of KIM, Alumni Kolej Islam (ALKIS) and others. UIM at present only offering postgraduate programmes the first study sessions for Master and PhD programs commenced on September 2015.

It is a continuation of Kolej Islam Malaya (KIM), established in 1955, and an institute of higher education with university status for the recognition given to the academic quality of the program certificate or diploma issue KIM is equivalent to a first degree University of Islamic Studies Outstanding World of Al-Azhar University, Egypt. UIM arguably pioneered by the state education endowments formation efforts already started many years ago. Once established, esteemed opinion on latest fatwa use endowment income that can be present in respect of endowment authority is affirmative scholars from Egypt during a conference organized by the UIM royal endowment in June 2012, where Dr. Ali Gomaah confirmed a ruling 
by the Fikh Academy of the Muslim World League in the 10th Conference in Mecca in October 1987 has decided to issue a fatwa of the endowment income in the public interest, unless it is a special endowment to continue to apply. So, UIM dominate the agenda of science education endowment traceability even its history is linked with the proceeds of the waqf.

UIM has moved forward by establishing an institute known as International Waqf and Islamic Finance Management Institute (i-WAFA) which has been declared on 12th of August 2014 by the university President in conjunction with the launch of Waqf Property Management Professional Course. The role of i-WAFA can be seen as following: "As the world's first and advanced research institute that combines Waqf Management and Islamic Finance and is characteristically crossdisciplinary".

Additionally, i-WAFA focuses on researches in term of comparative contemporary issues, in particular, the waqf and Islamic finance industry. i-WAFA also will contribute to the strengthening of human capital development of expertise in waqf and Islamic finance on the international arena. Findings of studies conducted by i-WAFA together with local and international experts in the field will benefit the country and humanity. i-Wafa has received recognition at the national level through CIMB Islamic endowment of Research Chair worth RM 1 million in the field of Waqf and Islamic Financial Management. In fact and in addition to that, CIMB Islamic has also contributed RM 1 million for the establishment of a special library for CIMB Islamic as the world's primary reference in the field of Islamic finance (http://www.uim.edu.my/v2/index.php/researchandinnovation/institutes-centres/i-wafa).

\section{Challenges}

It is material at this junction to also understand overview challenges of waqf in Malaysia which affect the implementation of waqf ecosystem in universities.

\section{Waqf and Malaysian Law}

Section 2 of the Waqf (State of Selangor) Enactment, 1999 (No.7 of 1999) defines waqf as: "The dedication of any property from which its usufruct or benefit may be used for any charitable purpose whether as Waqf Am or Waqf Khass according to Syaria, but does not include a trust which is defined under (the) Trustee Act 1949" (Trustee Act 1949). Below is a statistics of lands properties for waqf in states of Malaysia (Selangor Waqf Enactment 1999).

\begin{tabular}{|c|c|c|c|c|}
\hline \multirow{2}{*}{ BII. } & \multirow{2}{*}{ Negent } & \multicolumn{2}{|l|}{ Wakaf } & \multirow{2}{*}{$\begin{array}{c}\text { Jurnlah } \\
\text { Ekar(e ) }\end{array}$} \\
\hline & & Khas & Am & \\
\hline 1 & KELANTAN & $171.54 \mathrm{E}$ & $133.12 \mathrm{E}$ & 304.66 \\
\hline 2 & $\begin{array}{l}\text { WILAYAH } \\
\text { PERSEKUTUAN }\end{array}$ & 5.47 & 22.07 & 27.54 \\
\hline 3 & TERENGGANU & $204.43 E$ & $43.01 \mathrm{E}$ & 247.44 \\
\hline 4 & SARAWAK & $\begin{array}{c}93.9168 \text { hektar }+ \\
0.240 E+19489.2 \mathrm{sq} \\
\text { metres }=236.929 \mathrm{E}\end{array}$ & & 236.929 \\
\hline 5 & PAHANG & 3984 A 4.14 R $4.08 P$ & & 3985 \\
\hline 6 & SABAH & $4.178 \mathrm{E}$ & $25.42 \mathrm{E}$ & 29.598 \\
\hline 7 & JOHOR & 1951A. 2R. 23.01P & 3976A. 2R, 4.9P & 5928 \\
\hline 8 & PERLIS & $218.69 E$ & $8.75 E$ & 227.44 \\
\hline 9 & MELAKA & $773.39 \mathrm{E}$ & $69.97 \mathrm{E}$ & 843.36 \\
\hline 10 & KEDAH & $420 \mathrm{E}$ & $423.34 \mathrm{E}$ & $843.34 /$ \\
\hline 11 & NEGERI SEMBILAN & $1727.35 \mathrm{E}$ & $61.25 \mathrm{E}$ & 1788.60 \\
\hline 12 & SELANGOR & $621.10 \mathrm{E}$ & $442.15 \mathrm{E}$ & 1063.25 \\
\hline 13 & PERAK & $4474 E$ ER $30.02 \mathrm{P}$ & 647E 1R 7P & 5122 \\
\hline \multirow[t]{2}{*}{14} & PULAU PINANG & $22.21 \mathrm{E}$ & $67.05 \mathrm{E}$ & 89.26 \\
\hline & JUMLAH & $14,815.787$ & 5919.83 & $20,735.61$ \\
\hline
\end{tabular}


It is understood from this definition is that waqf refers to subject matter of waqf itself, that is waqf property or Mawkuf. While, in Selangor Waqf Enactment (No 7 of 1999) and the Melaka Waqf Enactment 2005, waqf is defined as follow: "The dedication of any property from which its usufruct or benefit may be used for any charitable purpose whether as Waqf Am or Waqf Khass according to Syaria, but does not include a trust which is defined under Trustee Act 1949 [Act 208]" (Melaka Waqf Enactment 2005; Selangor Wakaf Enactment 1999).

It is identified that waqf in the specific enactments in Selangor and Melaka refer to the act of the donor in dedicating his property as waqf and not the waqf property itself. Nevertheless, in Negeri Sembilan Waqf Enactment 2005, waqf means: (a) An endowment of title to any property from which may be enjoyed any benefit, interest or profit; (b) An endowment of any benefit, interest or profit which may be enjoyed from any property; or (c) The provision of expertise and services from which may be enjoyed any benefit, interest or profit, whether as as Waqf Am or Waqf Khass, in accordance with Syaria principles, but does not include a trust which is defined under the Trustee Act 1949 [Act 208] (Negeri Sembilan Wakaf Enactment 2005).

\section{University and Regulations}

Section 2 of Universities and University Colleges Act 1971 states that University or University College as higher educational institution having the status of a University or University College respectively. Section 2 of Private Higher Educational Institutions Act 1996, University or University College means a private higher educational institution conferred with the status of a University or University College under section 21, and include such private higher education. Institution which is affiliated to a University or University College whether within or outside Malaysia, conferred with the status of a University or a University College (Private Higher Educational Institutions Act 1996; Universities and University Colleges Act 1971).

\section{Conclusion}

Transformation implementation of educational endowment as an ecosystem in the higher learning institution for the moment needs to be supported by two basic things, even abstract but very relevant to higher education institutions in our countries really benefit from the advantages of this endowment in education.

Residents of higher learning institutions leadership must own and control the blend of intellectual and policy in the field through endowments for education. In Surah al-Baqarah, verse 269, for example, 'God grant wisdom (understanding in the Quran and the Sunnah) to whom He pleases. And whoever is given wisdom, it really has been awarded the gift of a lot. And the only person -the understanding that receive admonition.'

Wise leadership in supporting the learning of science is necessary to push the social impact related education endowment that is sometimes seen can lead to negative consequences. In fact, science and wisdom should be in line with the development of waqf property management system neat and orderly improved to a positive impact on the community at large (Wan Kamal et al. 2016b)

Accordingly, the religious endowment purposes as outlined in the Quran and the Sunnah are not only focused on the special endowments such as building mosques, graves or religious schools alone. In fact, the endowment can be extended to activities not only strengthen the economic position of Muslims, but also contribute to the economic development of a country. Imagine donated land in Malaysia's overall value now exceeds $\$ 60$ million, if it can be managed and administered by the party entrusted; it is certainly capable of generating economic growth in the future. The question is to what extent they trust or beneficiary, able to realize the dream of waqf giver the existence of various constraints in administering the waqf?

This situation also invites a sense of anxiety among donor endowment (al-Wakif) and the entire community for the implementation of the property management. There are still many scenarios where the donated land remained idle even 
though its location is quite strategic for the development of Muslims in terms of the economy, education or other social purposes.

Finally, waqf for education in Malaysia is still at the infant stage. It is important to understand the core principles of Waqf before transforming it into the university's income generation ecosystem. The power of state authority in issues relating to waqf is in contradicting to the higher education activities that fall within the ambit of federal matters (Wan Kamal \& Mohd Syakir 2016).

\section{References}

[1] http://www.uim.edu.my/v2/index.php/faw

[2] http://www.uim.edu.my/v2/index.php/research-andinnovation/institutes-centres/i-wafa

[3] Federal Constitution (As at 15th September 2014).

[4] Kartini Aboo Talib @ Khalid, Nidzam Sulaiman, Wan Kamal Mujani \& Ermy Azziaty Rozali. 2015. Membiayai pendidikan tinggi menerusi endowmen: kewibawaan

model Hibrid Harvard (Funding of higher education through endowment: Harvard hybrid model). Geografia Malaysian Journal of Society and Space, vol. 11 (4), pp. 121-131.

[5] Malaysia Companies Act 1965.

[6] Melaka Wakaf Enactment 2005.

[7] Mohamad Khairul Izwan Rifin, Wan Kamal Mujani \& Izziah Suryani Mat Resad@Arshad. 2014. Pembangunan wakaf dalam sektor keagamaan, teknologi dan kesihatan di Negeri Sembilan (The wakaf development in religion, technology and health in Negeri Sembilan). In Proceeding of the International Conference on Masjid, Zakat and Waqf (IMAF 2014). 1-2 December 2014, Kuala Lumpur, Malaysia, pp. 41-49.

[8] Mohamad Khairul Izwan Rifin, Wan Kamal Mujani \& Mohd Syakir Mohd Taib. 2016. Waqf and Endowment in Private University Malaysia. In Book of International Symposium on Waqf and Higher Education (ISWHE 2016). International Islamic University Malaysia (IIUM): Centre for Islamic Economics (CIE) Kulliyyah of Economics and Management Sciences (KENMS).

[9] Nor Suziana Mohamed \& Noor Inayah Yaakub. 2017a. Transformation of the role of waqf in Malaysia. Advanced Science Letters, 23(1), pp. 494-496.

[10] Nor Suziana Mohamed \& Noor Inayah Yaakub. 2017b. Educational Endowments Governance for Institutions of Higher Education in Malaysia: A Preliminary Study. Advanced Science Letters, 23(1), pp. 589-591.

[11] Mohd Syakir Mohd Taib, Wan Kamal Mujani, Noor Inayah Yaakub \& Mohamad Khairul Izwan Rifin. 2017. Wakaf pendidikan di Malaysia: suatu pengenalan (Waqf of education in Malaysia: an introduction). In Proceedings of the International Conference on Islam, Development and Social Harmony in Southeast Asia 2017. Bangi: Fakulti Pengajian Islam, pp. 389-395.

[12] Mohd Syakir Mohd Taib, Wan Kamal Mujani \& Mohamad Khairul Izwan Rifin. 2016. The scenario of waqf higher education in Malaysia and the responsibility of Malaysian government. In Book of International Symposium on Waqf and Higher Education (ISWHE 2016). International Islamic University Malaysia (IIUM): Centre for Islamic Economics (CIE) Kulliyyah of Economics and Management Sciences (KENMS).

[13] Negeri Sembilan Wakaf Enactment 2005.

[14] Private Higher Educational Institutions Act 1996.

[15] Selangor Wakaf Enactment 1999.

[16] Trustee Act 1949.

[17] Universities and University Colleges Act 1971.

[18] Wan Kamal Mujani. 2014. Pelestarian Institusi Wakaf untuk Memperkasa Pendidikan Tinggi Negara (The Sustainability of Wakaf for Strengthening Institutions of Higher Education). Bangi: Faculty of Islamic Studies, The National University of Malaysia. 
[19] Wan Kamal Mujani et al. 2012. A comparative studies between partition and sub-division of land under Mamluk Iqta' system and Malaysian National Land Code 1965. Journal of The Social Sciences, vol.7, no.2, pp. 189-195.

[20] Wan Kamal Mujani, Mohd Syakir Mohd Taib \& Mohamad Khairul Izwan Rifin. 2016a. Waqf higher education in Malaysia. In International Conference on Education, E-learning and Management Technology (EEMT 2016). Atlantis Press, pp. 519-522.

[21] Wan Kamal Mujani, Mohamad Khairul Izwan Rifin \& Mohd Syakir Mohd Taib. 2016b. Waqf in education sector of Negeri Sembilan, Malaysia. In International Conference on Education, E-learning and Management Technology (EEMT 2016). Atlantis Press, pp. 539-542.

[22] Wan Kamal Mujani, Mohd Syakir Mohd Taib \& Noor Inayah Ya'akub. Educational waqf (Islamic Endowment) in Malaysia. 2014. In Lecture Notes in Management Science 2014 - 2 ${ }^{\text {nd }}$ International Conference in Humanities, Social Sciences and Global Business Management (ISSGBM 2014). London, pp. 117-120.

[23] Wan Kamal Mujani \& Mohd Syakir Mohd Taib. 2016. Isu-isu Dalam Wakaf Pendidikan Tinggi (Issues in Wakaf Education). Bangi: Faculty of Islamic Studies, The National University of Malaysia. 